\title{
ON EARLY PSEUDO-LEARNED ORTHOGRAPHIC FORMS: A CONTRIBUTION TO THE HISTORY OF ENGLISH SPELLING AND PRONUNCIATION
}

\author{
JERZY WELNA
}

University of Warsaw

\begin{abstract}
The history of English contains numerous examples of "improved" spellings. English scribes frequently modified spelling to make English words and some popular borrowings look like words of Latin or Greek origin. The typical examples are Eng. island, containing mute $<_{\mathrm{s}}>$ taken from Lat. insula or Eng. anchor 'mooring device' ( $<$ Fr. ancre), with non-etymological $<\mathrm{h}>$. Although such "reformed spellings" became particularly fashionable during the Renaissance, when the influence of the classical languages was at its peak, "classicised" spellings are also found earlier, e.g. in texts from the $14^{\text {th }}$ century. In the present contribution which concentrates on identifying such earliest influences on spellings in Middle English attention is focussed on the regional distribution of reformed spellings, with a sociolinguistic focus on the type of the text. The data for the study come from standard sources like the Middle English Dictionary (2001) and Oxford English Dictionary (2009).
\end{abstract}

\section{Foreign influences on spelling}

It is common knowledge that the spelling patterns of foreign languages have exerted their impact on the spelling of English words. The problem is a rule debated the histories of English in the context of the English Renaissance. Thus, according to Culperer - Archer (2009: 251), "[t]he Early Modern period (...) saw huge interest in, and admiration for, classical Greek and Roman culture. Ancient Greek and Latin were extolled as perfect languages (...), whilst English was considered to be in a bad state". The so-called early grammarians in England found the state of their language far from satisfactory and even considered the English writing system as spoilt. John Hart, one of the most famous spelling 
reformers, who lived in the $16^{\text {th }}$ century, held that "there are four main ways in which a writing system could be "corrupt". These are, in his terminology:

1)

a. Diminution ("the use of too few symbols in the written form for the number of speech sounds to be represented").

b. Superfluity ("the use of more symbols in the written form than there are speech sounds in the spoken form").

These violations of the rule of good spelling can be exemplified by:

2)

(...) the $<\mathrm{b}>$ in doubt, the $<\mathrm{g}>$ in eight, $<\mathrm{h}>$ in authoritie, $<\mathrm{l}>$ in souldiours, $<\mathrm{0}>$ in people, $<\mathrm{p}>$ in condempned, $<\mathrm{s}>$ in baptisme, and divers lyke...

The two remaining corruptions, apparently less important, are:

3)

c. Usurpation ("the use of the wrong symbol. This arises because some symbols have "double powers', i.e. can be used to represent two different sounds"; e.g. " $g$ represents one sound in gentle but another sound in together, though in both cases it is followed by $e$ ").

d. Misplacing ("putting the written symbols in the wrong order"; e.g. fable, circle should be written fabel and cirkel, "because we pronounce the $e$ before the $l$, not after") (Barber 1997: 82-83).

Against the trends popularised in the $16^{\text {th }}$ century, Hart rejected "the idea that spelling should reflect the etymology of a word", i.e. the etymological spelling. This led to an extensive phenomenon of re-spelling, consisting in apparent "improvement" of English orthography.

The re-spellings mentioned above are usually associated with the Renaissance, which roughly overlapped with the new period in the history of the language, referred to as Early Modern English. Although the Renaissance is said to have begun in $14^{\text {th }}$ century Italy, the date of its beginning on the English soil is connected with either the introduction of the printing press by William Caxton in 1476 or with the accession of the Tudors and "culminating in the Elizabethan Age" (Bolton 1992: 860).

In describing the impact of classical languages and French on English spelling, the present short study concentrates on the data representing the period before the Renaissance, i.e. roughly the years 1200-1500, when many English words modified their spelling under the influence of not only Classical Latin, 
but also Vulgar Latin, Ecclesiastic Latin and Old French. The data come from two sources, the Oxford English Dictionary on CD-ROM (2009, the most recent version 4.0), and the Middle English Dictionary online (2001). The purpose of the study is to demonstrate that the Middle English period offers quite numerous evidence that the spelling patterns of Latin and of its various descendants had their share in modifying English spelling and producing pseudo Latin forms long before the Renaissance. A part of the problem has been already dealt with in my earlier paper (Welna 2002) on the reversed spelling of the sequence $<$ ar $>$ produced by the rule lowering short [e] before nonprevocalic [ $\mathrm{r}]$, as in $\mathrm{ME}$ serve clerk $>$ sarve clark which later restored the old orthography serve clerk due to the impact of the spelling of Lat. certus clericus, both containing the sequence $<$ er $>$. In the conclusion of the paper it was suggested that such influence of Latin had a strong sociolinguistic basis since the change in the sequence $<\mathrm{er}>$ "affected the pronunciation of vowels in the speech of certain social groups, i.e. those educated Englishmen who knew Latin and who were thus able to distinguish between loanwords containing [ar] produced by $e$-lowering and loanwords where [ar] was original", as in ME armee 'army'.

\section{Modified spellings: criteria of classification}

In Middle English, i.e. between the Norman Conquest and the introduction of the printing press by Caxton, the impact of the foreign patterns on the spelling convention of English is especially seen in certain graphemic contexts. The presentation which follows will only consider those modified segments which show at least some degree of the influence of the Latin spelling. The selection was made on the basis of listing in the long-forgotten monograph by Pumpjanskij (1963), a Russian linguist:

4)

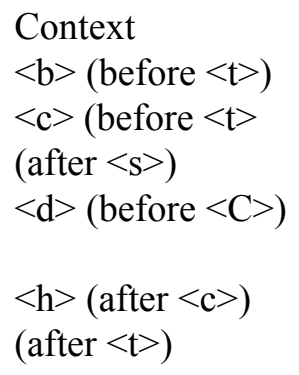

(word-initial)

\author{
Examples \\ debt, doubt \\ perfect, subject, verdict, victuals \\ sceptre, science \\ administer, admonish; advantage, adventure, \\ advert, advertise, advice, advocate \\ anchor \\ anthem, apothecary, theatre, theme, theology, \\ throne, thyme \\ habit, heir, herb, heretic, hermit, hermitage, \\ homage, honest, honour, horrible, host (mil.), \\ host, hostage, hostel, hour, humour
}




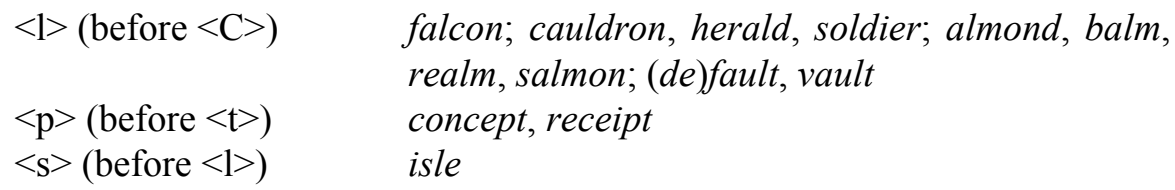

It should be made clear at this point that the term "pseudo-learned" used in the title need not convey a negative sense since in some instances, like in the case of the $<$ ar $>><$ er $>$ reversal discussed earlier, such modifications can be regarded as efforts to improve original Latin spellings corrupted by phonological changes in French or in English.

For practical reasons in the account which follows examples will be split into four groups, the first one embracing graphemes corresponding to plosives, i.e. $<$ b, $\mathrm{p}, \mathrm{c}, \mathrm{d}>$, the second containing words with non-initial $<\mathrm{h}>$, especially in the cluster $<$ th $>$ plus the noun isle, the third one contains words with initial $<\mathrm{h}->$, and the fourth group embraces words with preconsonantal $<\mathrm{l}>$.

\section{Graphemes $<b, \mathrm{p}, \mathrm{c}, \mathrm{d}>$}

This group of words with reformed spellings contains spectacular items like debt or doubt which are quoted in almost all textbooks of the history of English as spellings under a direct influence of Latin since the forms dette dout(e) borrowed from French later modify their orthography, inserting etymological $<\mathrm{b}>$ from Lat. debbitum. The $d$-less spelling is first found in the Ancrene Riwle (c.1230) and the spelling with $<\mathrm{b}>$ in a manuscript from the middle of the $15^{\text {th }}$ century, but a potentially older form can be found in an earlier document containing wills (texts from c.1415). Likewise, $\operatorname{doubt}(e / n)$, from French exhibits insertion of $<\mathrm{b}>$ :

5)

a. $\quad$ c.1230 (?a1200) 34a: We...ahen godd greate deattes of sunne...We seggeð: for3ef us ure deattes, alswa as we for3eoueð ure deatturs.

(*Ancr. Cambr. Corp-C 402 34a)

(1415) Pan my vessells of siluer...be sold and paied for my debtes wher myn other gods faillen.

(Wills Proved at Lambeth Palace HRS 2 28)

c.1450 (c.1405) $[\mathrm{He}]$ made vs...[T]o be his trewe attourneys and treete for his debtes.

(Mum and the Sothsegger) (Add 41666) 1710)

b. c.1230 (?a1200) Ne beon ha neauer se ancrefule ne se fulitohene, be deouel of helle duteð ham swiðe.

(*Ancr. Cambr. Corp-C 402 66a) 
(1429) The seide Suppliauntz doubten hem of damage and prejudice.

(Rolls of Parliament 4.346b)

c.1475 (?c.1451) Late it be out of doubte that...they by Goddis might shalbe overcome.

(The Book of Noblesse, Roy 18.B.22; 41)

If the influence of the Latin form on the spelling of debt with $<\mathrm{b}>$ seems certain because Old French apparently had no forms with $b$-insertion, there is evidence that the form doubter, with $<\mathrm{b}>$ (apart from duter, doter, douter) was present in $14^{\text {th }}-16^{\text {th }}$ century French, based on Lat. dubitâre, so that $d o u b t$, both a noun and a verb, can be direct borrowings from French in the middle of the $15^{\text {th }}$ century.

As regards the forms concept (conceit), receipt (receite), showing the insertion of the respective voiceless plosive [p], they can only be due to the imitation of Lat. conceptum and recepta (both PPs), since forms with $<\mathrm{p}>$ in English appear much earlier $\left(14^{\text {th }}\right.$ century) than in French $\left(16^{\text {th }}\right.$ century). The variation of the forms of both nouns can be seen in, for instance, Gower's Confessio Amantis; cf.:

6)

a. (a1393) The word was lich to the conceite,

Withoute semblant of deceite.

(Gower CA (Frf 3) prol.113)

Whan the word to the conceipte

Descordeth in so double a wise,

Such Rethorique is to despise.

(Gower CA (Frf 3) 7.1554)

b. (a1393) Aries...is the receipte and the hous

Of myhty Mars the bataillous.

(Gower CA (Frf 3) 7.991)

(c.1390) Denk also...Pat longe hast lyued and muche reseiued...hou pou hast spendet pat reseit.

(Mirror St. Edm. (1) (Vrn) 145)

Very similar in terms of word structure are four words (perfect, subject, verdict, victuals), containing the consonant cluster $<$ ct $>$ which may be a potential indication of the influence of Latin. Of the four items, perfect and verdict developed forms with $<\mathrm{ct}>$ undoubtedly under the influence of Lat. perfectum and MLat. verdictum. A hypothesis of a direct borrowing from Old French should be excluded since that language lacked forms with $\langle\mathrm{ct}\rangle$; $\mathrm{cf}$. 
7)

1591 (?a1425) (...) and before I come awaye my perfect sight I hadd.

(Chester Pl. (Hnt HM 2) 235/130)

(1433) ... duly and verily so founden by verdict of xii sufficient and indifferent persons of the ... Town

(Rolls of Parliament 4.479a)

Concerning the noun subject, it may be a direct borrowing (cf. Fr. subject, present in the $15^{\text {th }}$ century, although the early form in Trevisa may have reflected Latin influences). But the existence of OF victaille may be crucial in determining the French origin of victuals, although the vowel letter $<u<$ seems to indicate Late Lat. victualia as the direct source:

8)

c. 1330 16/325: Kes me, lemman, and loue me, And i pi soget [7S(2): soiet] wil ibe.

(7 Sages (1) (Auch) 16/325)

(a1398) 3if pe wit of gropinge is al I-lost, pe subiect of al pe beest is Idistroyed.

(*Trev. Barth. (Add 27944) 26b/b)

c.1436 (...) ne non other maner of thyng suspesious, for silver, ne for breed, ne for wyn, ne for ale, ne for other victuayle.

(Ipswich Domesday (2) (Add 25011 133)

In spite of their Latin look the two words in which the original initial $<\mathrm{c}->$ or $<\mathrm{s}->$ was replaced by etymological $<$ sc- $>$, sceptre and science, are rightly derived directly from French where the cluster $<\mathrm{sc}>$ is frequently found.

9)

(a1393) A worthi kniht... Of grete Rome...The Sceptre hadde forto rihte.

(Gower CA (Frf 3)2.589)

c. $1350 \&$ for pat pai ben of svtile science.

(Apoc. (1) in LuSE (Hrl 874)p.134)

In the course of time the above forms completely replaced rare spellings with a single initial consonant, like ciences (14c) or ceptre (Chaucer), which somehow failed to win popularity in English.

All potential doubts connected with the grapheme $<\mathrm{d}>$ in the last group are confined to words containing the prefix $a d$-. Although Old French words descend from Latin, clusters with the prefix-final $-d$ - and the following consonant $<\mathrm{v}>$ were in most cases simplified, losing that consonant. Consequently almost all English words belonging to this group refashioned their pronunciation from 
the French-like pattern to the Latin-like pattern, by inserting $<\mathrm{d}>$ from the Latin source word. This process belonged to the early half of the $15^{\text {th }}$ century, though $d$-full forms could be also found in the earlier texts (cf. Chaucer's use of both forms in the same text, i.e. Boece). The first occurrences of the latinised $d$-forms are the following:

10)

?a1425 (c.1380) To han wel adminystred the comune thynges...to profyt of the comune.

(Chaucer Boece (Benson - Robinson) 2.pr.7.20)

God...amynistreth, in many maneris and in diverse tymes, by destyne thilke same thinges that he hath disponyd.

(4.pr.6.98)

c.1450 (c.1440) The good Sperite... admonychyt owre mynde, he meuith oure will, and techyt owre vnder-stondynges.

(Scrope Othea (StJ-C H.5)101)

(a1470) By his deth ye shall have none advauntage.

(Malory Wks. (Win-C) 325/17)

c.1230 (?a1200) Swuch auenture bitimeð to..sum wummon, pet ha ne mei nawt fulleliche wreien hire seoluen

(Ancr. (Corp-C 402)92a)

(a1470) Sir Launcelot departed, and by adventure he com into the same foreste.

(Malory Wks. (Win-C) 264/6)

(?a1439) And beestis which be rage off ther nature, He can aduerte \& make hem li ful stille.

(Lydg. FP (Bod 263) 2.4043)

c. $1450 \mathrm{He}$ trowed pat onone with a wurd he sulde averte his purpos.

(Alph. Tales (Add 25719) 148/9)

(?c.1440) Y hafe found a cedule..of whyche I sende you a double, to be better avertysed of the mater.

(Paston2.50)

(?1464) That 3e myght ben advertysid and lernyd by theym the goode rewle...yn the despociscion and delyng of your almys

(Paston 4.119)

(c.1385) And if yow thynketh this is wel ysayd, Sey youre auys and holdeth yow apayd.

(Chaucer CT. Kn. (Manly - Rickert) A 1868)

(1425) By yowre advys...wryttes may ben taken agens hym.

(Paston2.21)

(a1387) Pe advoket his sone [Lat. oratoris filius]. 
(Trev. Higd. (StJ-C H.1)4.107)

(a1393) Ther was with him non advocat

To make ple for his astat.

(Gower CA (Frf 3) 7.2067)

Although all items printed in bold type are borrowings from French, these words owe their full prefix forms $a d$ - to their Latin source words. The dates of the first occurrences of the full prefix range from c.1425 (1380) (adminystre in Chaucer) to a1470 (adventure advauntage in Malory; MS date unavailable). As regards adminystre, it could have been influenced directly by a French form with $<\mathrm{d}>$ which was established in the late $14^{\text {th }}$ century, the original Old French form being aministrer, without $<\mathrm{d}>$. But practically in all other cases the $-d$ - in the respective French words reflects Latin influences during the Renaissance, while the English forms reflect such influences from before that period.

\section{Non-initial $<\mathrm{h}>$}

In our small corpus the non-initial $<\mathrm{h}>$ is typically found in the combination $<$ th $>$ in words of Latino-Greek origin, and in one word $<\mathrm{h}>$ appears in the cluster $<\mathrm{ch}>$ (anchor). It may come as a surprise that in this group of words the cluster $<$ th $>$ need not reflect a direct influence of Greek or Latin because that cluster can be found in the relevant French words, which means that the item could have been borrowed directly from French with no graphemic assimilation to the spelling of the classical languages. Words which owe their digraph spellings $<$ th $>$ to Old French are the following:

11)

a. (c.1390) Cristes moder swete...bad me for to synge

This anteme [vrr. anthephene, antheme,] verraily in my deiynge.

(Chaucer CT. Pri. (Manly - Rickert) B.1850)

b. (c.1384) Thei maden a sawt with oon ynwit, or wille, in to the teatre, or comune biholdyng place

(WBible(1) (Dc 369(2)) Deeds 19.29))

(c.1385) That swich a noble theatre as it was...in this world ther nas

(Chaucer CT. Kn.(Manly - Rickert) A.1885)

c. c.1400 (a1376) Panne tenide hym theologie

(PPl.A (1) (Trin-C R.3.14) 2.79)

d. c.1300 Thimus: anglice, time.

(Add. 15236 Herb List (Add 15236) 119)

(a1398) Epithimum is pe flour of thime, pat is a herbe.

(Trev. Barth.(Add 27944: Seymour) 948/21) 
The $<$ th $>$ spelling in theology is a norm, although the $h$-less orthography of this noun characterises spelling in Langland ( $P . P l$. A. xi. 136 Bote), while theatre exhibits forms without $<-\mathrm{h}->$ parallel to the digraph forms. Also thyme can be considered a direct borrowing from Old French since the form thym containing the $t h$-cluster is found in that language as early as the $13^{\text {th }}$ century. The most controversial item is anthem which lacked the Latin correspondence with $<$ th $>$, the only possible source form could only be rare OF anthaine but not LLat. antiphona which did not contain $<$ th $>$.

Words in which the digraph is in all probability due to the early influence of Latin and/or Greek are more numerous and include the following first occurrences of spellings with $<\mathrm{ch}>$ and $<$ th $>$ :

12)

a. (a1393) It blew and made such tempeste,

Non ancher mai the schip areste

(Gower $C A$ (Frf 3) 8.606)

b. (c.1387-95) Ful redy hadde he hise apothecaries [Cmb Ii: at the potecaries]

To sende hym drogges and his letuaries

(Chaucer CT. Prol. (Manly - Rickert) A.425)

c. c.1400 (?c.1380) Bot pe nwe, pat ly3t of Godez sonde, Pe apostel in Apocalyppce in theme con take.

(Pearl (Nero A.10) 944)

d. a1425 (?a1396) I cry the mercy, Kyng of Thrones.

(?Maidstone PPS .(Wht) 111)

Because Old French lacked the replicas with the digraph of the above set their form must have been influenced by Latin words like anachoreta, apothecarius, thema, and thronus. Such impact of Latin belongs mostly to the $14^{\text {th }}$ and early $15^{\text {th }}$ century.

A special case is the form of the noun isle. Old French substituted the form with $<$ s $>$, i.e. isle, for that of ile, apparently under the influence of Lat. insula 'island'. The rivalry of the two forms is reflected in the following examples:

13)

c. 1300 (?c.1225) Ihc was cristene a while; Po icom to pis ille [vr. yle] Sarazins blake.

(Horn (Cmb Gg.4.27) 1318)

(1446) The Kyng wol pat his letres...be directed to sir Thomas Stanley to carie...by

water Elianer Cobham in pisle of Man

(Proc. Privy C. 6.51) 
There is little doubt that Eng. isle was refashioned after the French form with $<-s->$, which became frequent in that language in the $15^{\text {th }}$ century, Although the Oxford English Dictionary derives the word from Old French as an $s$-less form ile, it is quite possible that the form with $<-\mathrm{s}->$ in English is a $15^{\text {th }}$ century reborrowing of the word.

\section{Initial $<\mathrm{h}->$}

The spelling and pronunciation of Middle English words with initial $<\mathrm{h}->$ is to a large extent determined by processes taking place in Vulgar Latin, Medieval Latin and Old French, i.e. languages showing a tendency to delete that fricative. The insertion of $h$ - before vowels in words where originally it had been lost may be interpreted in terms of hypercorrection (cf. Scragg 1974; Häcker 2004). This loss of the initial fricative caused a lot of confusion in the spelling convention, traces of which can still be found in Modern English where, for instance, the noun history or the adjective historical are sometimes preceded by the indefinite article an (cf. Visser's well-known title An historical English syntax).

The rather long list of words with word initial $<\mathrm{h}->$ in the present study reflects Middle English items with and without that consonant letter in their spelling. Explanations postulating the influence of Latin on the restoration of such $<\mathrm{h}->$ are not always credible since their vast majority had French correspondences with the initial fricative letter in spelling. In such cases the process of latinising was taking place not in English but in French, where the deleted initial $<\mathrm{h}->$ was frequently restored some time later. Under (14) are listed and exemplified words showing variation of $h$-full and $h$-less forms, sometimes in the same text; cf.

14)

ME $(h)$ abit $(<$ OF $(h) a b i t)$

c.1230 (?a1200) A wil pet ha alle habbeð i meane wið innen wið hare habit [Nero: abit], pet is an...

(Ancr. (Corp-C 402) 11/1)

$\mathrm{ME}(h)$ eir $(<\mathrm{OF}(h)$ eir $)$

c.1300 (?c.1225) Horn...Asla3en beb mine heirs...Mi Rengne bu schalt welde.

(Horn (Cmb Gg.4.27) 897)

(c.1300) be erl dede sone take pe knaue, Hauelok, pat was pe eir.

(Havelok (LdMisc 108) 410)

ME (h)eretike (< OF (h)eretique)

(1340) be heretike and pe apostate..reneyep hire bileaue.

(Ayenb. (Arun 57) 19/23). 
De lemes of anticrist..werrep pe guode men...ase deden..pe eretiks pe guode cristene men.

$(182 / 8)$

ME (h)ermite $(<\mathrm{OF}(h)$ ermite $)$

c.1275 (?a1200) 3urstendæi me com to an æremite [Otho: heremite] wel idon.

(Lay. Brut (Clg A.9) 18763)

ME $(h)$ omage < (OF (h)ommage)

(a1470) Ye shall have homage and feawte of me.

(Malory Wks. (Win-C) 314/21)

Hit were fayrer of hym to take omage and feaute and lat hym holde his londys of you.

$(325 / 16)$

ME (h)oneste ( $<$ OF (h)oneste)

(1340) be floures weren pe holy po3tes, pet alle weren uayre and oneste.

(Ayenb. (Arun 57) 96/10)

Panne pet stat of spoushod is zuo holy and suo honeste.

$(222 / 7)$

ME (h)onour ( $<$ OF (h)onour)

c. $1300 \mathrm{~W}$ ip gret honor hi hit [pe holi bodi] neme adoun and to buringe bere. (SLeg. And. (Hrl 2277) 101)

c.1325 (c.1300) Deie we raper wip onur.

(Glo. Chron. A (Clg A.11) 8176)

ME $(h)$ orrible $(<\mathrm{OF}(h)$ orrible $)$

(1340) bet him ne dret na3t to done ane greate zenne, dyadlich and orrible.

(Ayenb. (Arun 57) 43/5)

(c.1385) In derknesse and horrible and strong prisoun,

This seuen yeer hath seten Palamoun.

(Chaucer CT. Kn. (Manly - Rickert) A.1451)

ME (h)ost (< OF (h)ost)

c.1325 (c.1300)Hii asailede pe verste ost...Pe secunde ost of pe kinges alf...ne likede no3t pis cas.

(Glo. Chron. A (Clg A.11) 9421-8)

c.1325 (1265) Pe kyng of alemaigne gederede ys host

BLewes (Hrl 2253) 20

ME (h)oste (< OF (h)oste)

(c.1387-95) Greet cheere made oure hoost vs euerichon,

And to the soper sette he vs anon.

(Chaucer CT. Prol. (Manly - Rickert) A.747)

a1425(?c.1350) Efter soper, sayd myne oste

bat he cowth noght tel pe day 
Pat ani knight are with him lay.

(Ywain (Glb E.9) 222)

ME $(h)$ ostage $(<\mathrm{OF}(h)$ ostage $)$

c. 1300 As ri3t is bi ostage [Corp-C: hostage]

(SLeg. Pilate (Hrl 2277) 30)

ME (h)ostel $(<\mathrm{OF}(h)$ ostel)

a1400 (c.1303) He come and toke pere hys osteyl.

(Mannyng HS (Hrl 1701) 1938)

Whan synne ys shryue...Pere wyl God holde hys hostele

(12470)

ME (h)umour ( $<$ OF (h)umour)

a1425 Sip feveris is a siiknesse maad of distempour of humoures, and blood is moost kyndely umour, answeringe to pe love of...

(God. Wycl.Serm. (Bod 788)2.169)

Only two words with initial $<\mathrm{h}$-> among words subject to the present investigation may be considered to have modified their spelling under a direct influence of the Latin form. The two words are herb and hour, the latter with purely graphemic $<\mathrm{h}>$. The respective forms with initial $<\mathrm{h}->$ in French belong to a later period. The examples below indicate variation $\mathrm{cf}$. forms in both types:

15)

c.1300 Ioye pare was inov Of treon and herbes [Hrl: erbes] pikke j-nov3.

(SLeg. Brendan (LdMisc 108) 41-3)

(a1387) Pey puttep non giblettes [Lat. appendicia] to be houres [Tbr: oures] of Goddes service

(Trev. Higd. (StJ-C H.1) 7.403)

The above variation is found in the different manuscripts containing the same text.

\section{Preconsonantal <-1->}

Due to the vocalisation of preconsonantal [1] to [u] in French the sequence [al] develops into the diphthong [au] and such forms with the diphthong are often found in Middle English. Thus, the $<$ al $>$ spellings as a rule testify to the impact of the Latin form, Classical or Medieval, although some spellings contain $<1>$, perhaps reflecting Old French or Anglo-Norman forms. Consequently, quotations illustrating both types are split into two groups according to whether they are adjusted to French or Latin orthography. To the group of borrowings from French belong falcon, herald, soldier, almond, realm, salmon and vault, while 
the group of words with potential latinised spellings includes cauldron, balm, default and fault. The group revealing the influence of French spelling on English can be exemplified as follows:

16)

c.1275 (?a1216)Pe faucun was wrop wit his bridde.

$(O w l \& N .(\mathrm{Clg}$ A.9) 111)

c. 1450 bis lorde had also a gay falcon \& a swyfte.

(Alph. Tales (Add 25719) 68/6)

(c1385) An heraud [vrr. herowde, herod, herald] on a scaffold made on Oo

Til al the noyse of the peple was ydo.

(Chaucer CT. Kn.(Manly - Rickert) A.2533)

a1400 (a1325) He gadir sauders her and par,

To strenth his castels euer ai quar.

(Cursor (Vsp A.3) 24789)

?a1425 (?a1350) Of soldeyours to him soght So many knightes he had in oste.. Pat wele it semede...Vencuse him suld naman infight.

(Castleford Chron.) (Göt Hist 740) 20892

(a1398) Swete almoundes bep goode to mete and bitter almondes to medicyne...Neih al be tre pat berep bitter amoundes is medicynal.

(Trev. Barth. (Add 27944) 213a/b)

c.1330 (?a1300) bou hast made flem Pe ri3t aires out of pe rem

(Arth. \& M(Auch) 1642)

c. $1380 \mathrm{Y}$ am her bote a ...kni3t of pe realme of fraunce.

(Firumb. (1) (Ashm 33) 382)

(a1387) They etep hote samoun [Higd.(2): salmon; Lat. salmonem] alway, They phisik seie nay.

Trev. Higd. (StJ-C H.1) 1.407)

(1440) Vowte of a howse: Testudo, lacunar

(PParv. (Hrl 221) 512)

?c.1475 Bowe of a Brigge: volte

(?*Cath. Angl. (Add 15562) 17a)

As said earlier all these words may have been borrowed from French. which developed forms with restored $<\mathrm{l}>$ perhaps as a result of latinising. But in the other group French words could not serve as a model of restoring [1] for each of the respective forms with the liquid for their lack of $<\mathrm{l}>$; cf.:

17)

c.1300 A Caudron he liet fulle With eoyle; he liet it seope faste and pane guode man pareinne pulle. 
(SLeg. Cross (LdMisc 108) 383)

(a1393) Sche sette a caldron on the fyr.

(Gower CA (Frf 3) 5.4117)

(a1393) This Maister hath hire every joignt

With certein oile and balsme noignt.

(Gower CA (Frf. 3) 8.1198)

(a1398) Pure and verray bawme or balsamum may not be suffred in pe hond if the sonne come perto.

(Trev. Barth. (Add 27944) 216a/b)

1375 Gret defaut off mete had thai. Ibid. xiv.368 Defalt of mete

(Barbour Bruce ii. 569)

c.1330 (?a1300) Ded me were leuer...Pan he starf for faut of ous!

(Arth. \& M...(Auch) 7824

(a1393) As I am drunke of that I drinke, So am I ek for falte of drinke.

(Gower CA Frf 3, 6.286)

For lack of French correspondences with $<1>$, words in (17) must have based their $l$-full spellings on Lat. caldarium, balsamum, and VL *fallita.

\section{Concluding remarks}

To summarise the above evidence one can state that in spite of the prevailing views suggesting latinising of spellings of most words during the Renaissance, which, as said earlier, began in England at the turn of the $16^{\text {th }}$ century, there is ample evidence of forms latinised in the earlier manuscripts, even as early as those composed around 1300. Further, forms exhibiting Latin features, like certain consonant clusters, need not represent Latin patterns as they may be simply loanwords from Old French, a language subject to latinising earlier than English. Certain features, like the surviving initial prevocalic $<\mathrm{h}->$ in Middle English lexis almost always indicate the French origin of these words.

\section{REFERENCES}

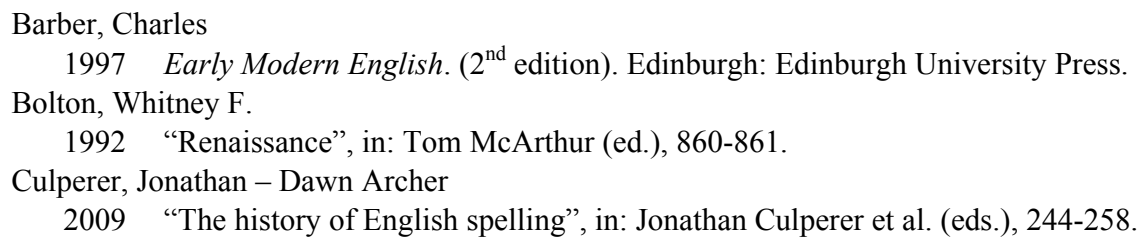


Culperer, Jonathan - Francis Katamba - Paul Kerswill - Ruth Wodak - Tony McEnery (eds.)

2009 English language. Description, variation and context. Lancaster: Palgrave- Macmillan. Häcker, Martina

2004 "Intrusive $[\mathrm{h}]$ in present-day English accents and $<\mathrm{h}>$-insertion in medieval manuscripts”, in: Christian Kay et al. (eds.), 109-123.

Kay, Christian - Simon Horobin - Jeremy Smith (eds.)

2004 New perspectives on English historical linguistics. Vol. 2. Lexis and transmission Amsterdam: Benjamins.

McArthur, Tom (ed.).

1992 The Oxford companion to the English language. Oxford: Oxford University Press.

McSparran, Frances (ed.)

2001 The Middle English Dictionary. Ann Arbor, MI: University of Michigan.

The Oxford English Dictionary on CD-ROM

2009 ( $2^{\text {nd }}$ edition) Version 4.0. Oxford: Oxford University Press.

Pumpjanskij, Aleksej Leonidovič

1963 Anglijskij literaturnyj jazyk (svjaz’ proiznošenija i pravopisanija).[English literary language (the relationship of pronunciation and orthography)] Moscow: Izdatel'stvo Akademii Nauk SSSR.

Scragg, Donald

1974 A history of English spelling. Manchester: Manchester University Press. Wełna, Jerzy

2002 "A change revarsed > reversed: the restoration of the nonprevocalic sequence [er] in English", Zeitschrift für Anglistik und Amerikanistik 50: 5-16. 